Please do not remove this page

RMIT

UNIVERSITY

\title{
Understanding poverty dynamics and economic mobility
}

Baulch, Robert (Bob)

https://researchrepository.rmit.edu.au/esploro/outputs/9921858636901341/filesAndLinks?institution=61RMIT_INST\&index=null

Baulch, R. (Bob). (2013). Understanding poverty dynamics and economic mobility. In Chronic Poverty: Concepts, Causes and Policy (pp. 38-59). Palgrave Macmillan.

https://researchrepository.rmit.edu.au/discovery/fulldisplay/alma9921858636901341/61RMIT_INST:Resea rchRepository

Document Version: Accepted Manuscript

Repository homepage: https://researchrepository.rmit.edu.au

(C) Contributors 2013

Downloaded On 2023/04/26 20:51:07 +1000 
Thank you for downloading this document from the RMIT Research Repository.

The RMIT Research Repository is an open access database showcasing the research outputs of RMIT University researchers.

RMIT Research Repository: http://researchbank.rmit.edu.au/

\section{Citation:}

Baulch, B 2013, 'Understanding poverty dynamics and economic mobility' in Andrew Shepherd, Julia Brunt (ed.) Chronic Poverty: Concepts, Causes and Policy, Palgrave Macmillan, Basingstoke, United Kingdom, pp. 38-59.

See this record in the RMIT Research Repository at:

http://researchbank.rmit.edu.au/view/rmit:22458

Version: Accepted Manuscript

Copyright Statement: (c) Contributors 2013

Link to Published Version:

http://trove.nla.gov.au/version/198295597 
Chapter published in Shepherd, Andrew and Brunt, Julia (eds) (2013), Addressing Chronic Poverty: Concepts. Causes and Policy, Basingstoke and New York: Palgrave McMillan

\title{
Chapter 3: UNDERSTANDING POVERTY DYNAMICS AND ECONOMIC MOBILITY
}

\author{
Bob Baulch
}

\begin{abstract}
This chapter examines the conceptualisation and measurement of poverty dynamics and economic mobility (PDEM). Poverty dynamics refers to intra- or inter-annual changes in welfare that cause individuals or households to cross a fixed, but essentially arbitrary, poverty line from one time period to the next. Economic mobility refers to the longer-term process, usually taking decades, through which individuals or households change their relative positions in the entire welfare distribution. Although usually couched in income or expenditure terms, any quantifiable continuous measure of welfare can be used to operationalise these concepts. Studies of PDEM in developing countries are, however, severely handicapped by the dearth of long-term multiple-wave panel dates sets and an inability to link their results with in-depth qualitative investigations of economic mobility and the life course. This chapter argues that descriptive analysis and a Q-squared approach that combines panel surveys with life histories in an integrated and sequenced manner offers great potential for gaining a more nuanced understanding of PDEM. Such an approach provides opportunities for learning and triangulation of findings across disciplines and promotes a deeper understanding of the opportunities and challenges poor people face.
\end{abstract}

\section{Introduction}

In recent years, the number of household panel data sets available for developing countries has increased dramatically and, along with these, the number of studies on 
poverty dynamics and economic mobility in low and middle-income countries (see Dercon and Shapiro, 2007; Fields et al., 2003). These studies confirm previous studies (Baulch and Hoddinott, 2000) that movements into and out of poverty are 'strikingly large', whether poverty is conceptualised in absolute terms (as in the poverty dynamics literature) or in relative terms (as in many studies of economic mobility).

This chapter examines the conceptualisation and measurement of poverty dynamics and economic mobility (PDEM) drawing on the ongoing work of the Chronic Poverty Research Centre in Bangladesh and Vietnam.

\section{Conceptual Challenges}

Poverty dynamics refers to intra- or inter-annual changes in welfare that cause individuals or households to cross a fixed, but essentially arbitrary, poverty line between one time period and the next. Economic mobility refers to the longer-term process, usually taking decades, by which individuals or households change their relative positions in the entire welfare distribution.

Transition matrices provide one of the simplest ways of examining poverty dynamics. The standard $2 \times 2$ poverty transition matrix shows the number (or percentage) of households who remain, move-out or into poverty, or remain non-poor between two survey years. Table 1 provides an example of a poverty transition matrix for Vietnam, constructed using the panel component of the Vietnam Household Living Standards Surveys. International experience shows that relatively large numbers of households move into or out of poverty between years, although it is difficult to compare the amount of poverty mobility across countries because of the different time periods and welfare metrics they use (Baulch and Hoddinott, 2000; Dercon and Shapiro, 2007). 
Table 1: Poverty Transition Matrix for Vietnam, 2002-2006

\begin{tabular}{|l|l|c|c|}
\hline \multirow{2}{*}{2002} & \multicolumn{3}{|c|}{2006} \\
\cline { 2 - 4 } & & Poor & Non-Poor \\
\cline { 2 - 4 } & Poor & 218 & 306 \\
\cline { 2 - 4 } & Non Poor & 67 & 1253 \\
\hline
\end{tabular}

Source: Baulch and Vu (2008)

There are a number of well-known difficulties with transition matrices. These include:

(i) if incomes (or expenditures) are measured with error, as is likely to be the case, some households will be erroneously classified. This is likely to be a particular problem for households with incomes that are close to the poverty line in one or both survey years;

(ii) households are classified as being poor or non-poor based on whether their incomes are above or below a pre-determined poverty line (which may or may not vary between survey years). Therefore transition matrices do not indicate how poor or well-off a household is; and

(iii) it is difficult to use transition matrices to compare poverty dynamics between countries, because the periods spanned by panel surveys and the welfare measures and poverty lines they use differ.

Contour plots, which can be regarded as the continous analogue of transition matrices are one way to circumvent the first and second of these difficulties. Contour plots are diagrams which provide a two dimensional view of a bivariate distribution, and resemble topological maps of mountains. ${ }^{1}$ They can be interpreted in a similar way to the contours on an topological map, except the contours represent points of equal frequency rather than points of equal height. Once horizontal and vertical lines representing the poverty lines in two survey years are superimposed on the contour

\footnotetext{
1 See Deaton (1997: 180-181) for further information on the construction and interpretation of contour plots.
} 
plot, its relationship to the four categories in a standard transition matrix become clear: the four partitions of the contour plot correspond to the four cells of the transition matix. Figure 1 shows an example of a contour plot for the same panel data from Vietnam that was used to construct Table 1.

\section{Figure 1: Contour Plot for Vietnam, 2002-2006}

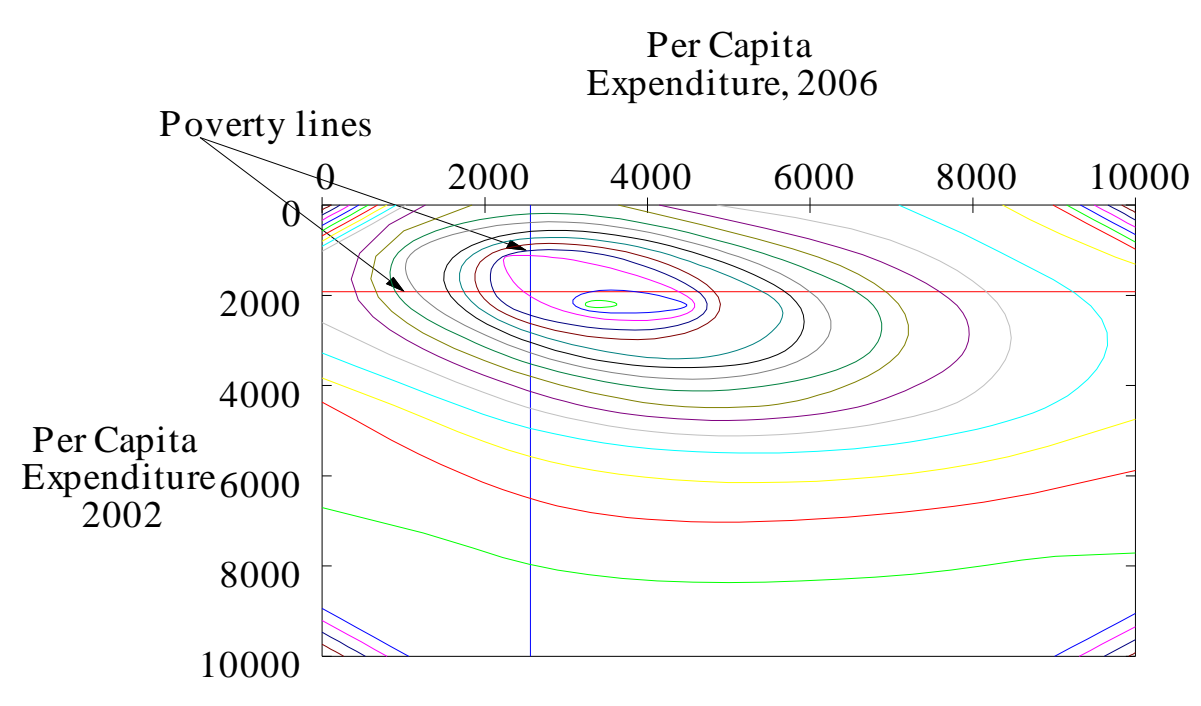

Source: Baulch and Vu (2008)

The position of the peak of the contour plot just inside the third quadrant (and particularly close to the 2002 poverty line) shows that while many households moved out of poverty between 2002 and 2006, large numbers of households in Vietnam remain vulnerable to falling back into poverty.

Another way of dealing with the second difficulty measured above is to construct extended poverty transition matrices, which divide the welfare distribution into categories based on fractions and multiples of the poverty line. See Table 2. While this procedure does not prevent households with incomes close to the poverty line from being misclassified, it does quantify how far above below the poverty line some households are able to move. 
There are also sophisticated measures using instrumental variables and statistical models for controlling for measurement error, which are reviewed in the next section.

Table 2: Extended Poverty Transition Matrix for Vietnam, 2002-2006

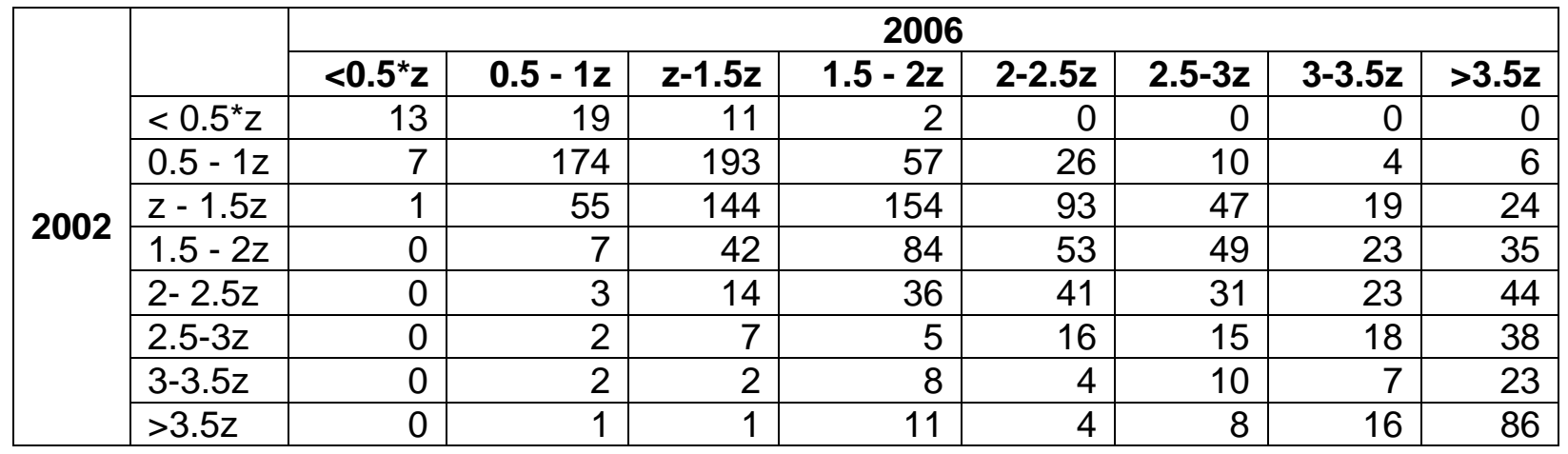

Source: Author's calculations from Vietnam Household Living Standards Surveys

Poverty hazard functions provide a way to address the third of the difficulties: the problems inherent in comparing transition matrices across countries and surveys. A poverty hazard function shows the probability of a poor household remaining poor in successive periods, and involves compounding the annual probabilities of staying poor so that they are consistent with the top left-hand corners of the poverty transition matrices. Figure 2 shows an example of a poverty hazard function for Vietnam. The slope of the poverty hazard function for Vietnam is slightly steeper between 2002 and 2004 than between 2004 to 2006, indicating that households were able to escape poverty more quickly during the earlier two year period. Furthermore, the last point on the hazard function shows that the probability of a poor household in 2002 still being poor in 2006 is just 0.17 . This in turn implies that about 28 percent (i.e., $0.17 / 0.61$ ) of the currently poor population have been poor for four consecutive years. While such a rapid reduction in the persistence of poverty is consistent with the improvements in most other welfare indicators in Vietnam, it is important to recognise that there are sections of the population (in particular the ethnic minority 
groups living in remote upland and mountainous areas), who have benefited to a much lesser extent from economic growth.

Figure 2: Poverty Hazard Function, Vietnam, 2002-06

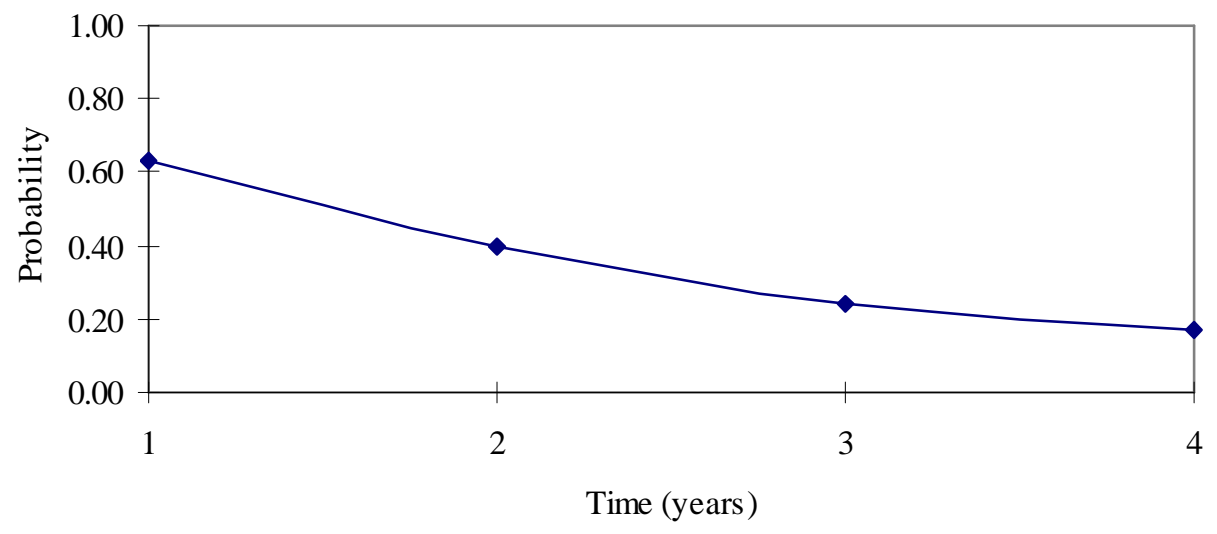

Source: Baulch, Chant and Robinson (forthcoming)

The derivation of poverty hazard functions is not, however, an easy task unless annual panel data is available, which is not the case in most developing countries. Baulch, Chant and Robinson (forthcoming) describe a methodology for doing so using cross-entropy techniques but to date this method has only been applied in South Africa and Vietnam. ${ }^{2}$

Poverty hazard functions can also be helpful in answering the question of how long a household or individual has to remain in poverty before being considered chronically poor? Based on the panel data that was available at the time, Hulme and Shepherd (2003) proposed a rough working definition of a five-year minimum duration for chronic poverty, while arguing that much chronic poverty is of considerably longer duration than this. ${ }^{3}$ However, a more conceptually satisfactory way of identifying this cut-off would be the point at which the poverty hazard function becomes flat. This

\footnotetext{
${ }^{2}$ For an example of a poverty transition function derived from annual panel data in Pakistan see Baulch and McCulloch (2003).

${ }^{3}$ Indeed, in the case of the intergenerational transmission of poverty, they argue that chronic poverty spans two or more generations.
} 
would correspond to the point at which the average household's or individual's chances or exiting poverty becomes both small and constant.

Finally, it is important to realise that although poverty dynamics are usually measured using money metric welfare measures (such as per capita or equivalised expenditures and incomes), as long as the requisite panel data is available, any continuous welfare measure can be used to operationalise these concepts. For example, Baulch and Masset (2003) use educational enrolments and nutritional zscores to construct poverty transition matrices for Vietnam between 1993 and 1998.

\section{Data Issues}

Two data issues pervade household panel studies in both developing and industrialised countries: attrition bias and measurement error. All existing household panels exhibit significant, although varying, degrees of attrition with urban areas being likely to experience higher levels of attrition (at the household level) than rural ones. ${ }^{4}$ Attrition causes three main problems for the study of poverty dynamics using household panels. First, the cumulative loss of households can greatly reduce sample size and statistical precision. Second, if attrition is non-random, analysis based only on the remaining sample will introduce selectivity bias as the sample becomes increasing unrepresentative of the population it was originally designed to represent. This is a particularly thorny problem when attrition depends on unobservables (variables that are not observed - at least by the survey instruments) in the first wave of a panel survey. Third, many significant factors of the poverty experiences of individuals and households are "suppressed" by the construction of balanced panels, although they are informative in their own right. Qualitative and participatory studies suggest that extreme poverty often leads to the migration of household members, the dissolution of households, and in the most extreme and

\footnotetext{
${ }^{4}$ For example, in a survey of attrition in three household panels, Alderman et al. (2001) find attrition rates varying from $6 \%$ to $50 \%$ of households between adjacent survey rounds.
} 
heart-rending cases, the death of unsupported individuals. A good deal more could be learnt about poverty dynamics if the factors leading to the attrition were studied systematically rather than "suppressed" by the creation of balanced panels.

There are a number of practical ways of reducing the level of attrition in household panels (Hill, 2000). These include collecting information on persons and "networks" with whom the household is associated in the first wave survey, using common household and personal ID codes in all waves of the panel, recording the exact position of households using GPS technology, and designing clear tracking protocols which specify how and when households should be tracked. ${ }^{5}$ Contrary to popular belief, many households do not move very far from their original residences, so that local tracking is not that costly. This was the tracking strategy adopted by the CPRCDATA-IFPRI panel in rural Bangladesh, which had a relatively low attrition rate of $6.3 \%$ of baseline households. Furthermore, as shown in Table 3, approximately four times more households split than were lost during the three periods spanned by this panel, the number of households in the panel actually increased by a fifth.

Long-distance tracking (for example of rural to urban migrants) is more difficult, but inter-wave follow-up visits and the provision of incentives to encourage households to report address changes and enumerators to track them can assist greatly. ${ }^{6}$ Thomas et al. report on the feasibility of long-distance tracking during the Indonesian Family Life Survey and show that they were able to reduce attrition to $5.6 \%$ over a four year period. They conclude that "following-up movers is an essential element of a successful panel survey" and that the costs of such tracking are "not prohibitive". Similarly, in north-west Tanzania, where the Kagera Health and Demographic Survey tracked both households and individuals over long distances, it was possible to track

\footnotetext{
${ }^{5}$ Other useful geo-referenced data (elevation, straight-line distances to nearest school, health facility, or market) can also be collected if GPS coordinates are collected.

${ }^{6}$ For example, in the Indonesia Family Life Survey, enumerators worked on tracking in pairs and were given a financial reward for each respondent they located.
} 
$93 \%$ of original households and $97 \%$ of individual respondents (Beegle, Dercon and de Werdt, 2006).

Table 3: Tracking and Attrition in the CPRC-DATA-IFPRI Bangladesh Panel

\begin{tabular}{|c|c|c|c|c|c|c|}
\hline \multirow[b]{2}{*}{ Study site } & \multirow{2}{*}{$\begin{array}{c}\text { Number of } \\
\text { households } \\
\text { in original } \\
\text { survey }\end{array}$} & \multicolumn{4}{|c|}{ Number of households in 2007} & \multirow[b]{2}{*}{ Attrition } \\
\hline & & $\begin{array}{l}\text { Households } \\
\text { lost due to } \\
\text { migration, } \\
\text { absence, } \\
\text { death, or } \\
\text { merging }\end{array}$ & $\begin{array}{l}\text { New } \\
\text { householc } \\
\text { to househ } \\
\text { division }\end{array}$ & $\begin{array}{l}\text { ds due } \\
\text { lold }\end{array}$ & $\begin{array}{c}\text { Total } \\
\text { number of } \\
\text { households } \\
\text { in } 2007 \\
\text { round }\end{array}$ & \\
\hline & & & $\begin{array}{l}\text { (Total) } \\
\end{array}$ & $\begin{array}{l}\text { (Interv } \\
\text { iewed) }\end{array}$ & & $(\%)$ \\
\hline Microfinance & 350 & 21 & 75 & 54 & 404 & 5.7 \\
\hline \multicolumn{7}{|c|}{ Agricultural technology } \\
\hline Improved vegetables & 313 & 13 & 109 & 96 & 409 & 4.0 \\
\hline Individual fishponds & 320 & 40 & 100 & 60 & 380 & 11.1 \\
\hline Group fish ponds & 324 & 15 & 139 & 124 & 448 & 4.4 \\
\hline $\begin{array}{l}\text { Educational } \\
\text { transfers }\end{array}$ & 480 & 31 & 62 & 31 & 511 & 6.1 \\
\hline Total & 1,787 & 120 & 485 & 365 & 2,152 & 6.3 \\
\hline
\end{tabular}

Source: Quisumbing (2007)

While tracking household splits is useful and should be done wherever feasible, it is an expensive and difficult activity. In such circumstances, it is essential to test for whether attrition is random and then control for its influence using one of two methods. The first method involves estimating a two-stage sample selection model in which the probability of attrition is modelled in the first stage (Heckman,1979). A second method used by Fitzgerald et al. (1998) involves applying inverse probability weights calculated by taking the ratio of the predicted probabilities of attrition calculated from probits (or logits) including and non-including the variables that are statistically associated with attrition. It is important to note, however, that these methods are based on observables only, and therefore only provide a partial correction for attrition bias. 
Measurement error poses a second serious problem for the study of poverty dynamics and economic mobility. Income and consumption expenditures (the welfare measures used by the vast majority of household panel studies) cannot be measured precisely, so some of the observed movements out of and into poverty will be statistical artefacts. While it is reasonable to assume that many of the reported movements out of and into poverty are genuine, the seriousness of measurement error and the extent of misclassification can be hard to detect. With panels for which there are at least three waves, it is possible to adjust for measurement error using simple correlations with a minimum of assumptions by adapting an approach proposed by Heise (1969). ${ }^{7}$ This approach relies on a lack of correlation between measurement errors in different panel waves to extract a reliability index which can be used to adjust observed expenditures or income. Table 4 shows the impact of applying this approach to adjusting for measurement error to the Vietnamese panel data reported above. With a reliability ratio of 0.911 , the number of chronically poor households and the number of never poor households increase by three to four percent, while the number of households moving out of or falling into poverty both fall -in the case of those moving out of poverty quite by around 15 percent.

Table 4: Poverty Transitions in Vietnam Adjusted for Measurement Error, 2002-2006

\begin{tabular}{|l|l|c|c|}
\hline \multirow{2}{*}{2002} & \multicolumn{3}{|c|}{2006} \\
\cline { 2 - 4 } & & Poor & Non-Poor \\
\cline { 2 - 4 } & Poor & 226 & 262 \\
\cline { 2 - 4 } & Non Poor & 57 & 1299 \\
\hline
\end{tabular}

Source: Author's calculations using Vietnam Household Living Standards Surveys

\footnotetext{
${ }^{7}$ See also Glewwe and Gibson (forthcoming).
} 
When panel data are only available for two points in time, as is often the case, other methods needs to be used to account for measurement error. Some of these methods (Fields et al., 2003 ) rely on instrumental variable estimation, others (Kuha and Skinner, 1997) on validation surveys and misclassification matrices , and still others on comparisons with proxy indicators (Rosenweig, 2003) or assets (Barrett et al., 2005) or comparisons on income and expenditure based poverty transitions (Woolard and Klasen, 2005). More sophisticated adjustments employ Markov models (Cappellari and Jenkins, 2002), latent structure analysis (Breen and Moisio, 2004) and pseudo panel analysis (Antman and McKenzie, 2005). Unfortunately, these methods are difficult to compare as they employ identification assumptions and have been applied to different data sets with different welfare measures, periodicity and instrumental variables. Nonetheless, nearly all studies conclude that measurement error considerably inflates estimates of poverty dynamics based on simple transition matrices and other descriptive measures. The integration of qualitative and quantitative methods discussed in the next sections provides an opportunity for examining some of the causes of measurement error along with the trajectories underlying poverty dynamics.

\section{Methodological Challenges in Integrating Qualitative and Quantitative Methods}

In recent years, there has been considerable interest in combining qualitative and quantitative methods in development research (see for example, Kanbur and Shaffer, 2007). However, there are many flavours to such 'q-squared' studies, which range from 'putting together' to 'full methodological integration' (Shaffer, 2003).

Internationally, 'putting together' studies are much more common than 'methodological integration', which can involve either undertaking qualitative and quantitative fieldwork simultaneously, or planning and sequencing qualitative and quantitative field studies with integrated analysis and write-up. Some leading 
examples of methodologically integrated Q-squared studies include Devereux and Sharp (2003) in Ethiopia, Parker and Kozel (2005) in India, and the four Well Being in Development countries (Gough and McGregor, 2007). The CPRC,s PDEM theme has sought to contribute to this literature by developing models for integrating and sequencing qualitative and quantitative methods for investigating poverty dynamics and economic mobility.

To date the CPRC's major effort has been the fielding of a major longitudinal study in rural Bangladesh, which combines focus group discussions, a traditional household panel survey and life history interviews in a sequenced and integrated fashion. Specifically, the study, which builds on three earlier evaluation studies of improved agricultural technologies, educational transfers and microfinance conducted by Data Analysis and Technical Assistance (DATA) and the International Food Policy Research Institute (IFPRI), had three phases:

Phase I was a qualitative phase designed to examine perceptions of changes (and why these have come about) from women and men in a sub-sample of the survey communities. This phase involved focus group discussions with four groups (of poor and better-off women, plus poor and better-off men) per village. The focus groups aimed to elicit perceptions of changes and the degree to which the three interventions affected people's lives (compared with other events in the community). A total of 116 single-sex focus group discussions, evenly divided between intervention and comparison control villages, were conducted in 11 districts in July and August 2006. The findings from these focus group discussions are described in Davis (2007).

Phase II was a quantitative resurvey of the original households from the IFPRI evaluation surveys together with any new households that have split off from the 
original households but remained in the same district. The household survey took place between November 2006 and February 2007, in the same agricultural season as the original surveys, and covered 2,152 households, of which 1,787 were core households that took part in the original survey, and 365 were "splits" from the original households (see Table 3 above). The overall attrition rate across the three sites was relatively low at $6.3 \%$ of core households across the three interventions. While attrition is not random - households with older members are more likely to leave the sample, and some location effects exist - tests suggest that the bias involved is not substantial. The initial findings from the quantitative resurvey are described in Quisumbing (2007).

Phase III consisted of a qualitative study based on life histories of 293 individuals from a sub-sample of 160 households in 8 of the districts in the original quantitative study. In each district, two villages from the Phase II study were selected. Then in each village 10 households were selected using the poverty transition matrices constructed using the original and 2007 household surveys. Life history interviews were carried out with, where possible, one man and one woman interviewed separately by two researchers of the same sex as the interviewee. 'Historical markers', such as the 1971 war of independence and 1988 floods were used to determine the years particular events described by the respondents occurred. All interviews were digitally recorded and written-up within a day or two of the interview. At the end of the life history interviews, a diagram of each respondent's life history from the time-line of events that he or she had drafted during the interview was also prepared. Fieldwork for this final phase of the study was undertaken between March and October 2007, and its initial findings are described in Baulch and Davis (2008).

The key findings concerning poverty dynamics and economic mobility which emerged from this study were as follows: 
- Using an expenditure-based poverty measure and the Bangladesh Bureau of Statistics poverty lines, monetary poverty was found to have more than halved in the three intervention sites. While at least half of the people surveyed moved out of poverty, around a fifth remained chronically poor. Between a quarter and a third were never poor, and a small percentage of people fell into poverty.

- The processes which lead individuals and households to escape from chronic poverty are gradual, and often interrupted by short-term set backs. As shown in Table 5, which is based on the life history subsample, most individuals included in the life history sub-sample experienced saw-tooth life trajectories, in which slow improvements in people's lives were combined with intermittent and sudden setbacks due to illness, dowry and wedding expenses, legal disputes and natural disasters

Table 5: Common Life Trajectories Patterns

\begin{tabular}{|c|c|c|c|}
\hline Direction & Pattern & Depiction & $\begin{array}{l}\text { Number } \\
\text { of Cases }\end{array}$ \\
\hline Stable & Smooth & & 8 \\
\hline Improving & Smooth & & 3 \\
\hline Declining & Smooth & & 2 \\
\hline Stable & Saw-tooth & & 135 \\
\hline Improving & Saw-tooth & & 76 \\
\hline Declining & Saw-tooth & & 30 \\
\hline Declining & Single-step & & 2 \\
\hline \multirow[t]{2}{*}{ Declining } & Multi-step & & 37 \\
\hline & & & 297 \\
\hline
\end{tabular}

These processes contrast strongly with the smooth processes or accumulation and decline that are hypothesised by standard neoclassical economic models, although it does not appear that asset trajectories bifurcate 
(split into two). Instead, there is evidence of convergence towards a single (low-level) equilibrium.

- The factors which lead individuals and households to fall into poverty are typically short-lived and associated with negative events at the individual or household, rather than community level. However, it is usually not a single negative shock but two or three negative events occurring in rapid succession, with insufficient time to recover in-between, which propel households into chronic poverty. In addition, some of the negative events, such as dowries and wedding expenses or the costs of medical care for elderly household members, are not strictly shocks at all as they are events which are predictable, at least approximately, in advance. However, it is covariant shocks, such as floods and harvest failure, that receive the most policy attention

While these findings demonstrate the value of combining qualitative and quantitative methods, it is important to realise that this is rarely a straightforward or easy task. Although the quantitative and qualitative methods used in the Bangladesh study had been careful sequenced and integrated using a common sub-sample, we discovered that a large number of the quantitative and qualitative poverty transitions did not agree with each other. Table 6 compares the quantitative and qualitative poverty transition categories for the same group of 293 of individuals. The quantitative transition categories, based on per capita expenditures and the Bangladesh Bureau of Statistics (BBS) poverty lines, correspond to the four cells in a standard $2 \times 2$ poverty transition matrix. The qualitative categories, shown on the horizontal axes, are based on a progressive scale developed during the life history interviews in which individuals classified their households as very poor if they had insufficient food to eat and poor if they were currently able to eat an adequate diet but vulnerable to food 
insecurity following a negative shock. ${ }^{8}$ In theory, these qualitative poverty cut-offs ought to correspond fairly well with the BBS's lower and upper poverty lines, but in practice around two-thirds of individuals were placed in different categories by the quantitative and qualitative analysis. As can be seen from Table 6, while the qualitative and quanttative data tend to agree about which people were chronically poor (PP) or never poor (NN), the life history interviews suggested many fewer households moving out of poverty than the household resurvey. This is related to the presence of measurement error in welfare measures (expenditures or incomes) used to define the quantitative poverty transitions.

Table 6: Comparing Quantitative and Qualitative Poverty Dynamics Categories

\begin{tabular}{|c|c|c|c|c|c|}
\hline \multirow[t]{2}{*}{$\begin{array}{l}\text { Quantitative matrix } \\
\text { categories }\end{array}$} & \multicolumn{4}{|c|}{$\begin{array}{l}\text { Qualitative matrix categories } \\
\text { (numbers of people) }\end{array}$} & \multirow[b]{2}{*}{ Total } \\
\hline & $\widehat{P P}$ & PN & NPP & TNN & \\
\hline$\overline{P P}$ & 58 & 1 & 4 & 11 & 74 \\
\hline PN & 75 & 4 & 15 & 31 & 125 \\
\hline NP & 20 & 0 & 2 & 6 & 28 \\
\hline$\overline{\mathbf{N N}}$ & 17 & 9 & 2 & 38 & 66 \\
\hline Total & 170 & 14 & 23 & 86 & 293 \\
\hline
\end{tabular}

Source: Davis and Baulch (2009)

To reconcile these differences, Davis and Baulch (2009) use a sequential approach to explain these mismatches, focusing first on using assets rather than expenditures to measure welfare, and the closeness of per capita expenditures to the poverty line. Non-expenditure based measures of well-being, changes in household size, and qualitative recall errors were then examined as potential explanations of the

\footnotetext{
8 Households who owned less than 6 bighas ( 2 acres) of land were particularly likely to vulnerable in this way.
} 
mismatches. ${ }^{9}$ Table 7 shows that cumulatively these five factors reduce the mismatches between the qualitative and quantitative analysis by three-quarters. Using land assets rather than expenditures to measure welfare resolved $43 \%$ of these mismatches, while closeness of expenditures to the poverty line, accounted for another $31 \%$ of the discrepancies. Both these factors are consistent with the discussions of misclassifications and measurement error earlier in this chapter. However, re-examination of the life history interviews reveal that non-monetary wellbeing issues (due, for example, to ill-health and domestic violence) and probable qualitative recall errors account for $15 \%$ and $6 \%$ of the mismatches, respectively. Neither of these factors would be detectable using a conventional household survey. Finally, the use of adult equivalent rather than per capita expenditures to adjust for changes in household size reduces the mismatches by another $11 \%$ suggesting that adjusting for differences in household composition and size is important when measuring poverty dynamics. ${ }^{10}$

Table 7: Sequential Reduction of Mismatches between Quantitative and Qualitative Poverty Dynamics, rural Bangladesh

\begin{tabular}{|l|c|c|}
\hline & Individual (\%) & Cumulative (\%) \\
\hline Total \% of Mismatches & $\mathrm{n} / \mathrm{a}$ & 66.9 \\
\hline Land not expenditures & 43.4 & 35.2 \\
\hline Close to poverty line & 30.6 & 23.5 \\
\hline Well-being not expenditures & 14.7 & 20.5 \\
\hline Changes in household size & 11.3 & 15.7 \\
\hline Qualitative recall errors & 5.5 & 14.3 \\
\hline
\end{tabular}

Note: based on 293 matched household questionnaires and life histories

Source: Davis and Baulch (2009)

\footnotetext{
${ }^{9}$ Another potential explanation of the mismatch included the presence of lumpy expenditures (such as health expenditures and dowries) that were non-welfare enhancing. However, care was taken to ensure that these were eliminated from the household expenditure aggregate.

${ }^{10}$ This last finding also has implications for the welfare measure and poverty lines used by the BBS in its cross-sectional poverty monitoring exercises
} 


\section{Measuring Economic Mobility}

Economic mobility refers to the longer-term process, by which individuals or households change their relative positions in the welfare distribution. In contrast to the relatively short periods spanned by most studies of poverty dynamics, economic mobility is measured over periods of decades or even between lifetimes in the case of intergenerational mobility. Since mobility is usually measured with reference to changes in rankings (often percentile based) in the welfare distribution, it is also conceptually different from movement across a fixed poverty line. Nonetheless, there are a number of interesting parallels with the poverty dynamics literature.

First, economic mobility can be measured across a number of different dimensions. Sociologists tend to examine mobility in terms of social class or occupation classifications, while economists and statisticians tend to focus on monetary measures of mobility (Fields, 2001) Economic mobility can also be related to changes in height (Steckel, 1995), and to health and nutrition (Behrman and Deolalikar (1988).

Second, like poverty dynamics, economic mobility can be either upward or downward and there are strong reasons to suggest that the processes which lead to the improvements in living standards are gradual while downward movements occur more rapidly. For example, in South Africa, Cichello et al. (2003) have shown that the vast majority of those who are upwardly mobile are those who obtain and retain formal sector employment. Socially excluded groups also tend to be less upwardly mobile than the mainstream population, especially when they do not speak the same language or share the same customs and religions (Meerman, 2005).

Third, age and life-cycle effects are likely to have a strong impact on both economic mobility and poverty dynamics. As one would expect, the mobility of earnings tend to 
be significantly higher for younger people than for older ones. In Germany, Trede (1998) found that earnings mobility declined sharply until the age of around thirty-five before levelling out. The way mobility declines with age resemble the way poverty hazard functions flatten out with time.

Fourth, there is a range of mobility measures in use which, like poverty measures, tend to be either discrete or continuous. Discrete measures, such as the Shorrock's immobility index, are often two-stage indices derived from transition matrices while continuous measures, such as correlation coefficients and the Gini index of mobility, are computed directly from unit record data on earnings, expenditures or incomes. ${ }^{11}$ Fields (2001) distinguishes between mobility measures (such as rank correlation coefficients and quantile changes) which are measures of positional movement, and other measures (such as Shorrock's immobility index and standard correlation coefficients) which reflect how individuals' share of total income change. Still other measures (such as those proposed by Fields and Ok, 1996) capture symmetric or directional income movement. Fields stress how the use of different mobility measures typically leads to different conclusions about the type of mobility experienced, and the need for an axiomatic foundation to the measurement of mobility.

Van Kerm (2009) has recently proposed a simple but useful graphical device to portray mobility which he calls the 'income mobility profile'. This involves plotting the expected growth in income (or any other continuous measures of welfare) against a person's position in the welfare distribution. ${ }^{12}$ Although this graph only captures certain aspects of changes in mobility, Van $\operatorname{Kerm}(2009,1)$ argues that this device is

\footnotetext{
${ }^{11}$ Discrete mobility measures, however, do tend to over-estimate relative persistence in the tails of the distribution, for the simple reason that persons in the poorest welfare group cannot move down a group while those in the top welfare group cannot move up (Jarvis and Jenkins, 1998).

${ }^{12}$ Mobility profiles resemble growth incidence curves in the pro-poor growth literature (Ravallion and Chen, 2003). However, as Van Kerm (2006) points out their interpretation is different because the focus is on the entire distribution rather than parts of it, such as the poor or poorest quintile.
} 
useful because debates about mobility often involve an implicit view that "'it is good, from a societal points of view, if poor people climb up the income ladder' rather than mobility being driven by changes in the incomes of the better off. By examining, the slope and shape of mobility profile we can learn whether the pattern of growth tends to favour the richer or the poorer.

Figure 3 shows an example of a mobility profile for rural Bangladesh, constructed using per capita expenditures from the agricultural technology portion of the CPRCDATA-IFPRI panel described above. The profile slope downwards suggesting that growth in welfare is higher (in proportionate terms) for those starting toward the bottom of the distribution in 1996. The profile also suggests that from a mobility point of view, economic growth in rural Bangladesh has been pro-poor rather than poor rich. Indeed when vertical lines corresponding to the percentage of the poor in 2006, or the chronically poor in both years, are inserted onto the profile, it can be seen that the poor experienced higher rates of expenditure than the non poor while the chronically poor fared better than the initial poor. It is important to stress, however, that these changes rates to proportionate rather than absolute changes: so that in monetary terms, richer people still experience larger changes in their welfare levels. 
Figure 3: Mobility Profile for rural Bangladesh, 1996-2007

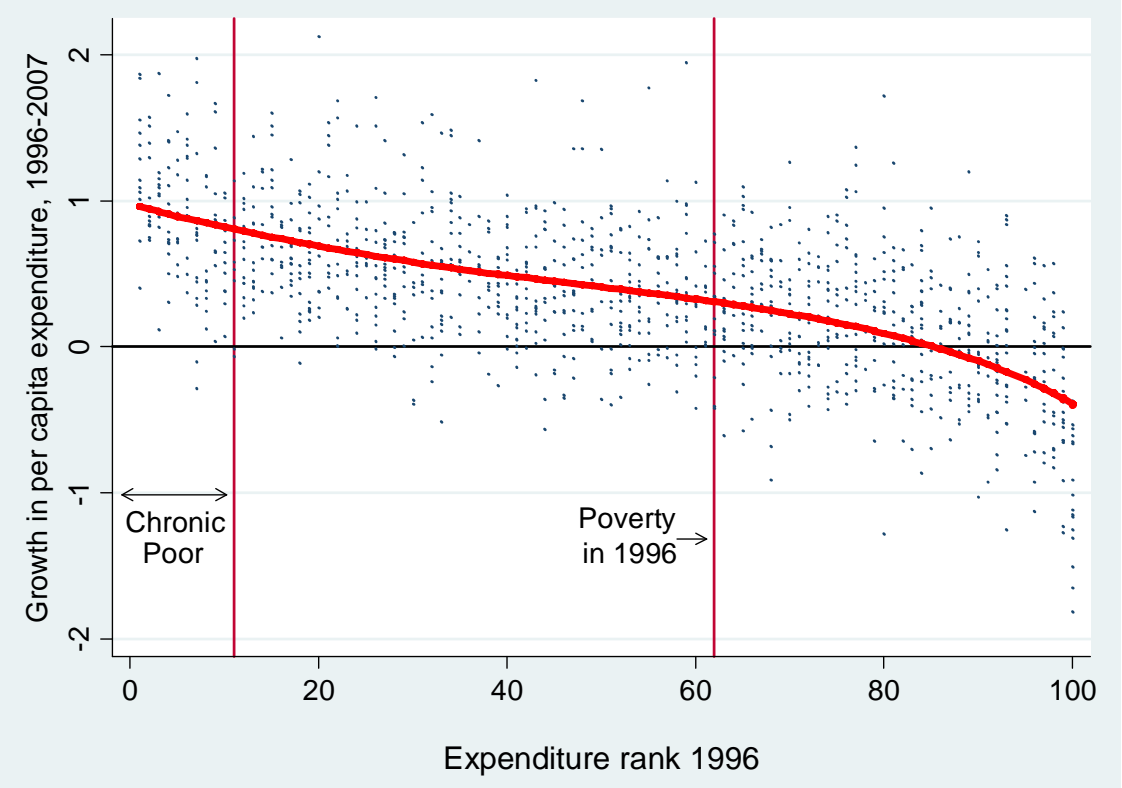

As with poverty dynamics, measurement error can make a substantial difference to economic mobility. This is because if the welfare variable is measured with error, and measurement error across periods is not correlated, this will make it appear that there is more mobility than there actually is. Van Kerm (2006) also suggests a useful and simple way to check how much mobility is due to measurement error: constructing the ranks in the initial period using a proxy variable, which is highly correlated with the welfare variable but not with measurement error. Figure 4 implements this suggestion using the value of assets per capita, which are also available for the Bangladesh data set. While the alternative mobility profile using asset ranks still slopes downwards but is now much flatter than it is before. Furthermore, the slopes at the tails (edges) of the distribution disappear, suggesting that measurement error is especially important in the tails of the distribution (as one would expect it to be). The sleeper slope of the original mobility profile constructed using expenditure ranks is also consistent with another well known statistical phenomenon related to measurement error: the reversion to variables to their means. 
Figure 4: Mobility Profiles with Alternative Ranking Variables

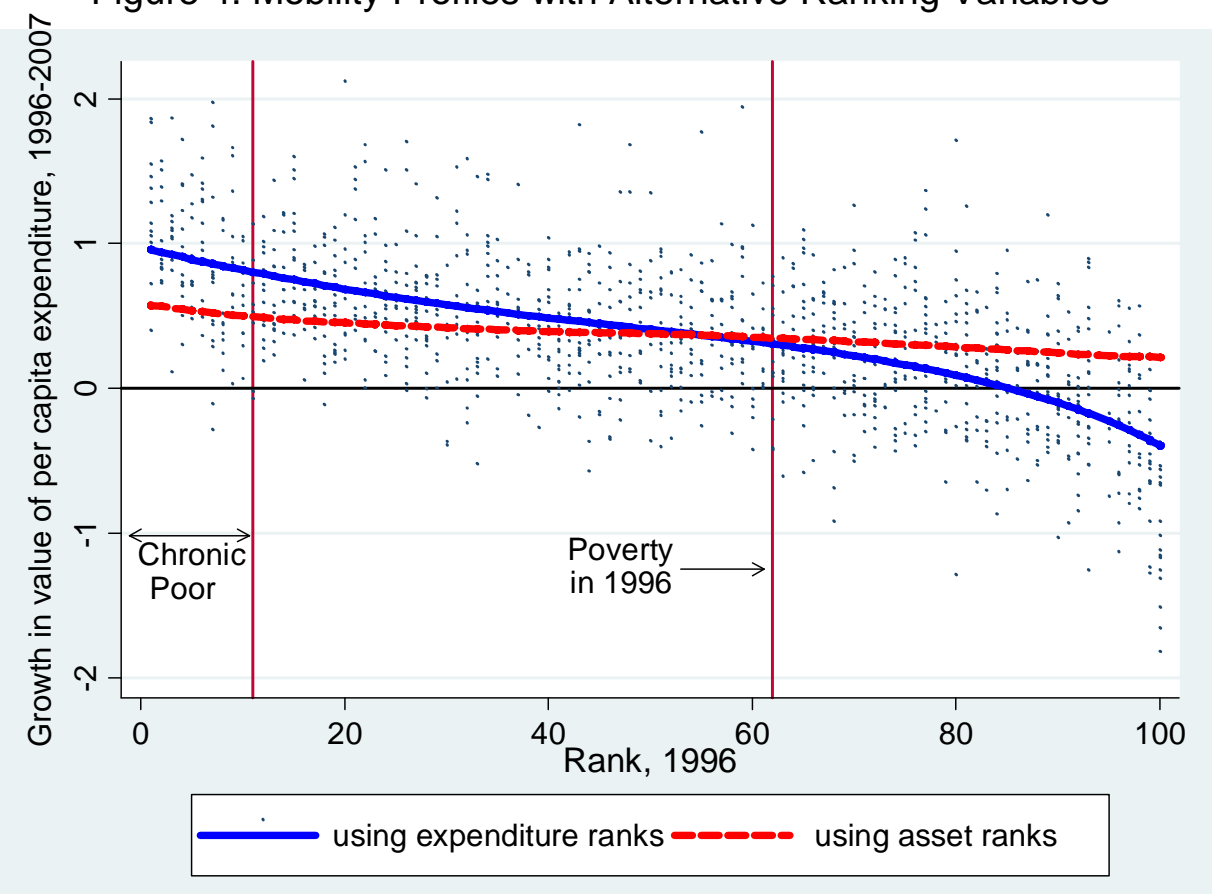

Finally, just as a high level of poverty transitions tends to reduce the incidence of chronic poverty, greater economic mobility tends to reduce the amount of long-term inequality. Individuals long-term welfare will tend to equalise with mobility, because those with unfavourable positions in the welfare distribution in one survey wave are often not the same of those with unfavourable positions in the next survey wave. As noted by Jenkins and Van Kerm (2003), different levels of mobility can explain the seeming paradox between growth that is pro-poor and rising levels of static inequality. This is related to the well-known phenomenon that static snap-shots of welfare distributions (such as the Lorenz curve and Gini coefficient) tend to exaggerate overall inequality (Yitzaki and Wodon, 2002).

While the study of economic mobility has much to offer for the analysis of chronic poverty, it must be recognised that most panel data sets in developing countries are too small (in terms of observations) and too short (in terms of time) to allow the detailed analysis of the phenomenon that has been possible in America and Europe. Nonetheless, many of the insights gained about mobility in high-income countries 
may be expected to carry over to low- and middle-income economies. With declining levels of absolute poverty and a growing number of long-term panels in developing countries, research into economic mobility may be expected to expand in the future.

\section{Conclusions}

This chapter has reviewed the state of art in the conceptualisation and measurement of poverty dynamics and economic mobility with special reference to the CPRC's work.

It finds that there are significant conceptual challenges and measurement issues associated with the conventional analysis of poverty dynamics based on transition matrices. The most important of these are attrition bias and measurement error. The value of integrating qualitative and quantitative methods was then discussed with special reference to the CPRC's work in rural Bangladesh. Although qualitative and quantitative methods often produce some findings about poverty transitions which appear to be inconsistent, interrogating these mismatches provides great potential for gaining a more nuanced understanding of PDEM. In so doing, researchers can gain deeper understanding of the reality of chronically poor people's lives. Finally, the importance of broadening out the concept of poverty dynamics to include economic mobility more generally was outlined. As level of absolute and chronic poverty decline over time, there is likely to be greater interest in economic mobility issues in the developing world.

\section{References}

Alderman, H., Behrman, J., Kohler, H.P., Maluccio,J. and Watkins, S (2001) 'Attrition in longitudinal household survey data', Demographic Research 5(4): 79-124

Antman, F. and McKenzie, J (2005) 'Earnings mobility and measurement error: a pseudo-panel approach', Policy Research Working Paper 3745, World Bank, Washington DC

Barrett, C., Maryenya, P. P., McPeak, J. Minten, B. Murithi, F, Oluoch-Kosura, W., Place, F., Radrianarisoa, J. and Rasambainarivio, J. and Wangilia, J. (2005), 
'Welfare Dynamics in rural Kenya and Madagascar', Journal of Development Studies 42(2): $248-277$

Baulch, B., Chant, L. and Robinson, S. (forthcoming) 'Between the waves: estimating poverty dynamics and economic mobility using limited survey data with applications to Vietnam and South Africa', CPRC Working Paper

Baulch, B, and Davis, P. (2008) 'Poverty dynamics and livelihood trajectories in rural Bangladesh', International Journal of Multiple Research Approaches 2(2)

Baulch, B. and Hoddinott. J. (2000) 'Poverty dynamics and economic mobility in developing countries', Journal of Development Studies 36(6): 1-24

Baulch, B. and Masset, E. (2003) 'Do monetary and non-monetary indicators tell the same story about chronic poverty? A study of Vietnam in the 1990s', World Development, 31(3): 441-454

Baulch, B. and Vu, H.D. (2008) 'Poverty dynamics in Vietnam, 2002-2006', Background Paper for 2008-09 Poverty Assessment, Vietnam Academy of Social Sciences, Hanoi

Beegle, K., Dercon, S. and de Weerdt, J,. (2006) 'Orphanhood and the long-term impact on children', American Journal of Agricultural Economics 88(5): 1266-1272

Behrman, J,. and Deolalikar, A. (1988) 'Health and nutrition', Handbook of Development Economics Vol 1, New York: North Holland

Breen, R. and Moisio, P. (2004) Poverty dynamics corrected for measurement error', Journal of Economic Inequality, 2: 171-191

Cappellari, L. and Jenkins, S. (2002), 'Who stays poor? Who becomes poor?

Evidence from the British Household Panel Survey', Economic Journal 112, C60-67

Cichello, P. Fields, G. and Leibbrandt, M. (2003) 'Earnings and employment dynamics for Africans in post-apartheid South Africa: a panel study of KwaZulu-Natal' Working Paper 03/77, Development Policy Research Unit, University of Cape Town

Davis, P., 2006, 'Discussions among the poor: exploring poverty dynamics with focus groups in Bangladesh', CPRC Working Paper 73.

Davis, P. and Baulch, B. (forthcoming), 'Parallel realities: exploring poverty dynamics using missed methods in rural Bangladesh' draft CPRC Working Paper

Deaton, A. (1997) Analysis of Household Surveys: A Microeconometric Approach to Development Policy, Baltimore: John Hopkins University Press

Dercon, S. and Shapiro, J., (2007), 'Moving on, staying behind, getting lost: lessons on poverty mobility from longitudinal data', GPRG Working Paper Series 75, Oxford: Global Poverty Research Group

Devereux, S., Sharp, K., and Amare, Y., 2003, 'Destitution in Wollo, Ethiopia', IDS Research Report 55, Brighton: Institute of Development Studies

Fitzgerald, J., Gottschalk, and Moffit, R. (1998) 'The impact of attrition in the PSID on intergenerational analysis', Journal of Human Resources, 32(2): 300-344 
Fields, G. (2001) Distribution and Development: A New Look at the Developing World, Cambridge: MIT Press

Fields, G., Cichello, S. Freiji, S., Menendez, M. and Newhouse, D. (2003) 'Household income dynamics: a four country story', Journal of Development Studies 40(2): 30-54

Fields, G. and Ok, (1996), 'The meaning and measurement of economic mobility', Journal of Economic Theory, 71: 349-377

Glewwe, P. and Gibson, J, (forthcoming) 'Analysis of poverty dynamics', in Handbook of Poverty Statistics, United Nations Statistical Division, New York

Gough, I. \& McGregor, J.A. (2007) Wellbeing in Developing Countries: From Theory to Research, Cambridge: Cambridge University Press.

Jarvis, S. and Jenkins, S. (1998) 'How much income mobility is there in Britain?', Economic Journal 108(447): 428-443

Heckman, J. (1979) 'Sample selection bias as a specification error', Econometrica 47: 153-161

Heise, D (1969) Separating reliability and stability in test-retest correlation', American Sociological Review 34(1): 93-101

Hill, Z., 2002, "Reducing attrition in panel studies in developing countries", Young Lives Working Paper No. 5

Hulme, D. and Shepherd (2003), 'Conceptualizing chronic poverty', World Development 31(3): 403-423

Jenkins, S. and Van Kerm, .P. (2003) 'Trends in income inequality, pro-poor income growth and income mobility', ISER Working Paper 2003-27, University of Essex

Kanbur, R. and Shaffer, P. (eds.) (2007) 'Experiences of combining qualitiative and quantitative approaches in poverty analysis', Special Issue of World Development $35(2)$

Kuha, and Skinner, (1997) 'Categorical data analysis and misclassification' in Lyberg, L. et al. (eds) Survey Measurement and Process Quality, New York; John Wiley

Luttmer, E.F.P. (2001) 'Measuring poverty dynamics and inequality in transition economies: disentangling real events from noisy data', Policy Research Working Paper 2549, World Bank, Washington DC

Meerman, J. (2005) 'Economic mobility of the socially excluded', Journal of SocioEconomics 34(4): 542-567

McCulloch, B. and Baulch, B,. (2000) 'Simulating the impact of policy upon chronic and transitory poverty in rural Pakistan', Journal of Development Studies 36(6): 100130

Parker, B. and Kozel, V., 2005, 'Understanding poverty and vulnerability in India's Uttar Pradesh and Bihar: a Q-squared approach', Q-Squared Working Paper 9, Centre for International Studies, University of Toronto 
Quisumbing, A. (2007) 'Poverty transitions, shocks, and consumption in rural Bangladesh: Preliminary results from a longitudinal household survey', CPRC Working Paper 105.

Ravallion. M. and Chen, S. (2003) 'Measuring pro-poor growth', Economics Letters 78(1): 93-99

Rosenzweig M (2003) Payoffs from panels in low-income countries: economic development and economic mobility, American Economic Review 93(2): 112-117.

Shaffer, P. (2003) 'Difficulties in combining income/consumption and participatory poverty approaches: issues and examples' in Kanbur, R. (ed), Qualitative and Quantitative Poverty Appraisal, Delhi: Permanent Black

Steckel, R. (1995) 'Stature and the standard of living', Journal of Economic Literature XXXIII: 1903-1940

Thomas, D., Frankenberg, E. and Smith, J. (2001) 'Lost but not forgotten: attrition and follow-up in the Indonesian Family Life Survey', Journal of Human Resources 36(3): 556-592

Trede, M. (1998) 'The age profile of mobility measures: an application to West Germany', Journal of Applied Econometrics 13(4): 397-409

Van Kerm, P. (2006) 'Comparisons of income mobility profiles', IRISS Working Paper 2006-06

Van Kerm, P. (2009) 'Income mobility profiles’ Economics Letters 102(1): 93-95

Woolard, I. and Klasen, S. (2005) 'Determinants of income mobility and household poverty dynamics in South Africa', Journal of Development Studies 41(5): 865-897

Yitzaki, S. and Wodon, Q. (2002) 'Mobility, inequality and horizontal equity', Mimeo, World Bank, Washington DC 